\title{
Editorial
}

\section{Which Governance Structure for Law Making Projects Regarding Emerging Technologies?}

We are all, more and more, convinced that the major fault lines characteristic of today's legal systems are the impact of Information Technology (IT), more particularly the emerging (or so-called "disruptive") technologies, on the law and how the law can contribute to reversing our changing climate. In the Netherlands, but not only there, the latter aspect has drawn quite some attention because of the recent decision by the Netherlands Supreme Court in the "Urgenda case", demanding the government to reduce the level of greenhouse gases with $25 \%$ before the end of $2020{ }^{1}$ The decision seems quite severe, especially in a country where the Constitution forbids the judiciary to decide on the constitutionality of statutes, but at the same time allows that same judiciary to rule on the compatibility of these very statutes with international treaties. The decision brings to the surface the growing tensions within the country's political system (legislature and executive) and its judiciary. However, except when it comes to privacy protection, no such far-reaching and principled cases seem to have thus far reached Supreme Courts in Europe in the area of IT and law, for example regarding the legal nature of smart contracts (i.e. self-executing computer programmes), replacing more traditional standardised or boilerplate contracts. Although legislation in this area seems to be growing, particularly when looking at the micro-jurisdictions within Europe (Malta, Liechtenstein), still many questions are unanswered and even in states with a beginning of a legislative framework no case law has developed yet. ${ }^{2}$

1 Hoge Raad (Netherlands Supreme Court) 20 December 2019, ECLI:NL:HR:2019:2006; more information (with texts in English) can be found on https://www.rechtspraak.nl/Bekende -rechtszaken/klimaatzaak-urgenda.

2 For Malta see https:/www.loc.gov/law/foreign-news/article/malta-government-passesthree-laws-to-encourage-blockchain-technology/ and for Liechtenstein https:// 
As is the case with climate change, the field of emerging technologies is, I would say by definition, an international area, given the cross-border nature of the developments. Even though old notions of state sovereignty are returning with the introduction of IT walls around countries, as is done in China and Russia, and considered by others, albeit for the time being in a more limited way to block certain criminal content. Given this international nature various international organisations are, or are becoming, active in this field to create practice oriented governance structures, aiming to establish a worldwide level playing field and thus promoting international trade. At the same time, as could have been expected, national governments attempt to gain control of this international process by enacting national laws from the policy viewpoint of that particular country in the hope to gain a better international bargaining position. This is nothing new. It is, furthermore, a phenomenon that seems to fit well within this era of disintegration, in Europe the prime example being of course Brexit, but also looking at the desire of certain European regions to become not only more autonomous but to be recognised as independent states.

Organisations looking for solutions at an international level are, on a global scale, for example the United Nations Commission on International Trade Law (UNCITRAL) and in Europe, on a regional scale, the European Law Institute (ELI). UNCITRAL was created in 1966 and now is a well-established global organisation. The European Law Institute was founded in 2011, modelled after the American Law Institute (ALI), and aims to promote better law making in Europe. ${ }^{3}$ The ELI has various projects in the area of emerging technologies and the law. With one exception, all of these projects are done by project teams, consisting of participants from various backgrounds and jurisdictions, supported by the ELI secretariat. The teams receive feedback from an Advisory Committee, a Members Consultative Committee and so-called "Assessors". Members of an advisory committee are experts in the field and are selected. However, any ELI member can be involved in a Members Consultative Committee. Assessors are specialists who evaluate the final project outcome, to

impuls-liechtenstein.li/en/blockchain-act-liechtenstein/. For an overview cf. Tom Lyons, Ludovic Courcelas and Ken Timsit, Legal and regulatory framework of blockchains and smart contracts, A thematic report prepared by the European Union Blockchain Observatory and Forum (Brussels, 2019): https:/www.eublockchainforum.eu/sites/default/files/reports/ report_legal_vi.o.pdf and for an overview from the perspective of tax law: Robby Houben and Alexander Snyvers, Cryptocurrencies and blockchain, Legal context and implications for financial crime, money laundering and tax evasion, Study requested by the TAX3 committee of the European Parliament (Brussels, 2018): http://www.europarl.europa.eu/cmsdata/150761/ $\mathrm{TAX}_{3} \% 20$ Study\%20on\%2ocryptocurrencies\%20and\%2oblockchain.pdf.

3 The history of the European Law Institute can be found at: https://www.europeanlawinstitute.eu/about-the-eli/history/. 
support the ELI Executive Committee, the Council and the Membership of the ELI when the decision has to be taken, whether the outcome can be qualified as an ELI instrument. The (preliminary) results of a project are discussed in the ELI Council and at the ELI annual meeting. The one exception, where no project team as such exists, but where only the two "reporters" are solely responsible for drafting the text, is the project on "Principles for a Data Economy". The reason for this somewhat different approach is the global nature of the project, as it is the outcome of a collaborative effort of the American Law Institute and the European Law Institute. The ALI has project "reporters", specialists in their field, who are responsible for the text and who work rather independently without a project team as sounding board. It is the primary role of ALI advisors to give feedback, which gives them a more prominent role. Although the name of this project seems to imply that it will present a complete legal framework not unlike in Europe the (Draft) Common Frame of Reference was meant to be a framework for a European Civil Code - the principles are of a more limited nature. ${ }^{4}$ The ELI website gives the following explanation: "With the rise of an economy in which data is a tradeable asset globally, more certainty is needed with regard to the legal rules that are applicable to the transactions in which data is an asset. Critical questions arise such as who has which right with regard to the data generated by connected devices? They need to be answered urgently, as lack of clarity in this field potentially hinders innovation and growth and, more importantly, troubles consumers, data-driven industries, and start-ups." To put it briefly, the principles concentrate on transnational data transactions between Europe and the United States. It steers away from highly contested questions such as "data ownership", although it will be clear that data transactions require the presence of parties with a legal interest in data, otherwise a transaction would be "empty".

The other ELI projects in this area concentrate on the platform economy (the project team is working towards "draft model rules on online intermediary platforms"), digital eco-systems (blockchain technology and smart contracts) and access to digital assets. ${ }^{5}$ All these projects have in common that a revisiting of existing private law is needed. Can, to give but one example, a legally binding agreement be reached in the form of a "smart" contract? Can the content of a blockchain be qualified as "digital content" in the sense of the digital

4 See for more information the website of the European Law Institute (https://www.europeanlawinstitute.eu/projects-publications/current-projects-feasibility-studies-and-other-activities/current-projects/data-economy/) and the American Law Institute (https://www.ali.org/ projects/show/data-economy/\#_status).

5 For an overview see: https://www.europeanlawinstitute.eu/projects-publications/current -projects-feasibility-studies-and-other-activities/. 
content directive? ${ }^{6}$ How should information duties be distributed over the participants in a platform? These are all very fundamental questions and the answers will be crucial for how the law might deal with emerging technologies.

Given the vital role of organisations such as UNCITRAL and the ELI in the development of how the law should adapt to emerging technologies, the governance structure of their projects is of utmost importance. A clear balance should be reached between the various interests at stake. Given the uncertainty in this area, too quick, and perhaps as a consequence: one-sided, solutions are an inherent danger when, for example, the voice of individual users is not heard clearly enough. The ELI offers in this respect a, what might be called, more democratic structure. Unlike is the case with its American counterpart the ALI, the number of members is not capped. Furthermore, the annual fee for individual members is quite moderate. Any member has the opportunity to become involved in any project through Members Consultative Committees and participation in the annual meeting. This facilitates and encourages involvement of everyone with an interest in this area. Active participation in the work of the European Law Institute is therefore strongly encouraged!

\author{
Sjefvan Erp \\ Editor EJCL; Professor of Civil Law and European Private Law, \\ Maastricht University, The Netherlands \\ s.vanerp@maastrichtuniversity.nl
}

6 Directive (EU) 2019/770 of the European Parliament and of the Council of 20 May 2019 on certain aspects concerning contracts for the supply of digital content and digital services, OJ $2019 \mathrm{~L} 136 / 1$. According to the directive (article 2, (1)), "digital content' means data which are produced and supplied in digital form". This is a very wide definition. 